\title{
'Crises of Modernity' Discourses and the Rise of Financial Technologies in a Contested Mechanized World
}

\author{
Marinus Ossewaarde ${ }^{1}$
}

Received: 29 April 2016 / Accepted: 26 February 2017 / Published online: 11 March 2017

(C) The Author(s) 2017. This article is published with open access at Springerlink.com

\begin{abstract}
The aim of this article is to provide a discussion of scholarly 'crisis of modernity' discourses that have developed in the field of social philosophy. Revisiting past and present discourses can be illuminating in at least three ways: it can reveal the broader picture of the present financialized and technologized world and the rise of financial technologies; it can provide scholars with new vocabularies, concepts, and metaphors to comprehend present-day phenomena and developments; and it can reveal the variety of commitments that are possible, today, too. This article starts with a discussion of the original 'crisis of modernity' discourses (avant la lettre), in which the clashing arguments of Comte and Tocqueville are featured, and a discussion of a second 'crisis of modernity' that developed in the context of the 'Great Depression.' A third 'crisis of modernity' discourse emerged in the wake of the financial crises of the 1970s. Such crises are still ongoing and discussed within the boundaries of the third 'crisis of modernity' discourse. How financial technologies do and do not fit within this third discourse is discussed in the remainder of this article.
\end{abstract}

Keywords Crisis · Democracy · Financialization · Financial technologies · Ideology · Mechanization modernity discourses

\section{Introduction}

In discourses on the 'crises of modernity' during the past two centuries, technology is an important theme for philosophical reflection. In such discourses, the turmoil that characterizes the development of new worlds is often conceived as being closely related to technological changes and, more recently, to so-called financial technology

Marinus Ossewaarde

m.r.r.ossewaarde@utwente.nl

1 University of Twente, Enschede, Netherlands 
innovations (Strange 1986: 27; Coyle 2011: 183). In the 1830s, two renowned social thinkers, a technological optimist and pessimist, namely, Auguste Comte and Alexis de Tocqueville, sought to formulate a 'new science' to conceptualize and respond to the transformations of worlds brought about by the French Revolution and the Industrial Revolution. They entertained different ideas about the causes of the revolutionary changes and crises through which European societies were going through. The divergence between these two views is illustrative of the manifoldness of the discourse of 'modernity' (a word first coined by Charles Baudelaire in 1864), reflecting the clashing ideas regarding the nature of 'modern society' and of modern man, as well as different hierarchies of human goods, values, ideals, or commitments. In Comte's narrative, industrial technology defines and makes 'modernity.' The latter is propounded as a progress of human civilization. The new world is an industrial, technological society, in which engineers and technocrats are the key agents who ensure the further technological development. Along this line, if there was any crisis of modernity, it referred to the transitional revolutionary phase towards technological modernity. The revolutionary phase was unnecessarily lengthy because ancient, outdated dogmas, prejudices, privileges, and superstitions of bygone priestly worlds, as well as time-consuming political debates and struggles, stood in the way of the inevitable industrial development. In Tocqueville's narrative, on the other hand, 'modernity' primarily means democracy and, in particular, the equality of living conditions beyond aristocratic privileges. The new world is marked by its post-aristocratic political constellation in which citizens, civil, and political associations are expected to realize the ideals of the French Revolution and thereby shape a democratic culture. For Tocqueville, 'modernity' was in crisis because this expectation was not being fulfilled; instead, the political arena was dominated by what he identified as political demagogues like Adolphe Thiers and Louis Napoleon.

The divergence between the Comtean and Tocquevillian interpretations of the modern condition and its predicaments reflects different appraisals of industrial technology and modern politics. For Comte, technology promised liberation and meant the end of chaotic political clashes, debates, and revolutionary upheavals; for Tocqueville, technology could potentially become a weakening and enslaving force. Only a vibrant political culture could prevent administrative despotism that was facilitated by industrial technologies. The Comtean and Tocquevillian legacies, which represent two opposing poles in thinking about technology, can be discerned in later discourses, till today. Those who embrace the Comtean optimist belief in industrial technologyunderstood as the product of mechanist thinking and application of engineering methods - tend to value technological progress above political and cultural flourishing. Those who follow in the footsteps of thinkers like Tocqueville are sceptical about the prospects of technology. They tend to prioritize cultural and intellectual greatness, which, according to them, stand in tension with mechanization and non-democratic rule (and hence not technology as such). The conceived causes of, and remedies to, the crises of the modern world depend on the chosen conceptual frameworks. The aim of this article is to provide a discussion of scholarly 'crisis of modernity' discourses that, in the historical context of particular political and financial crises, have developed in the field of social philosophy (Sim 2010; Roseman 2011; Harrington and Roberts 2012). Re-visiting past and present discourses can be illuminating in at least three ways: it can reveal the broader picture of the present financialized and technologized world and the 
rise of financial technologies; it can provide scholars with new vocabularies, concepts, and metaphors to comprehend present-day technological developments; and it can reveal the variety of philosophical commitments that are possible, today, too.

This article starts with a discussion of the original 'crisis of modernity' discourses (avant la lettre), in which Comte and Tocqueville are featured. In the second section, the 'Great Depression' of the 1920s and 1930s is taken as the context where liberal and radical discourses of modernity developed. In this second discourse, scholars expressed themselves in the liberal commitment to, and radical criticism of, the redistributive welfare state and its launching of large-scale social programs and technological initiatives. The third section focuses on the third 'crisis of modernity discourses' that developed in reaction to the financial crises of post-industrial capitalism of the 1970s. The era of neoliberalism had dawned: a powerful financial sector and the reprogramming of the welfare state (post-Keynesian crisis management) uncoupled post-industrial technology (particularly derivative-based technology) and democracy. As financial technology and finance came to operate against 'the people' and labour, the argument goes, a crisis of democratic culture developed. This crisis, as argued in the final section, is still ongoing. The latest big financial crisis, in 2008, is a manifestation of a condition that has become structural and it is in this neoliberal context that new (typically algorithm-based) financial technologies have come to rise rapidly. The general tenor of contemporary discourses is that there is an urgent need for creativity and the corresponding imagining of a democratic and culturally humanist alternative to the present thoroughly financialized world. There is currently the strong awareness, most strongly articulated by Colin Crouch, that the 'crisis of modernity' is such that no viable democratic alternative to post-Keynesian financialization can be realized without transcending the mechanical, algorithmic structures of financial capitalism, yet scholars also stress that from the global financial crisis, new financial technological and democratic pathways can emerge.

\section{The First 'Crisis of Modernity' Discourse}

The first 'crisis of modernity' discourses emerged in the nineteenth century, in response to the political, social, and financial crises that emerged in the context of the French Revolution and the Industrial Revolution. The original 'crisis of modernity' discourses developed in the context of chaotic events, such as the 1830 July Revolution, the 1848 February Revolution, the economic crisis of 1857-1958, the 1871 Paris Commune, the Paris Bourse crash of 1882, the decade of recession (1882-1892), 1914 (World War I), and the making of the Weimar Republic (1919-1933). Such discourses were defined by a clash between technological optimists that welcomed the Industrial Revolution and technological pessimists that feared that the Industrial Revolution would undermine the development of a democratic culture (cf. Tiles and Oberdiek 1995). Technological optimists, Auguste Comte in particular, emphasized the benefits of the mechanization of the world. For him, this mechanized world was patterned on a Galilean worldview, the technological mastery of nature, and 'the de-natured environment' (Mumford 1971: 51). Technological pessimists, such as Alexis de Tocqueville and the German romanticist philosophers, argued that such mechanization destroys the prospect of making democracy work and of shaping a new world of cultural flourishing of the mind. 
Mechanization, in their view, destroys the European culture of Europe's political and cultural elites. What were the key scholarly arguments of this first 'crisis of modernity' discourse?

Comte, similarly to some other enlightenment optimist thinkers, identified industrial technology as the application of mechanical, Newtonian science. He believed that the crises and revolutions of the nineteenth century could be overcome through the negation of ancient European metaphysical (including Platonist, Aristotelian, and Thomist) ways of thinking and the enforcement of an industrial techno-culture that was rooted in mechanist principles (Comte 2000: 39). Industrial technology, in his view, promoted sociality: the issues that divide or unite people were to be settled in tangible, socialist arrangements of things that he identified as 'scientific politics' (Comte 1974: 151). What harmed the world, according to Comte, was politics and dialogue. Politics and dialogue were premised upon outdated, metaphysical, or teleological foundations. According to him, these were outdated because it had become clear that all realities (nature, technology, society) operate by the same Newtonian principles. 'The only danger to be feared, the only needful precaution,' Comte (1974: 107) explains, 'is that of not allowing ourselves to be turned aside from the end by the intrigues of ambitious men, who dispute among themselves the falling remnants of the ancient system'.

But not all social philosophers believed that the mechanization of the world would be the way to overcome the turmoil of the nineteenth century. Comte's contemporary, Tocqueville, was far less euphoric at the prospect of a 'technological modernity.' Though he shared Comte's distaste for industrial capitalism, he did not believe in a socialist arrangement of things and the enforcement of technocratic or depoliticized administration. Taken a more sceptic view, like the ancient philosophers, he argued that industrial technology could potentially become an enslaving force. Technology 'seems to have been useful only for sugarcoating and legitimizing servitude,' Tocqueville (cited in Ossewaarde 2004: 149) noted. In a mechanized world ruled by calculating and measuring engineers and technocrats who come to replace the wise philosophers and statesmen, the line between desires and needs was blurred, artificial needs were multiplied, and the spiritedness that had always characterized the citizen was thereby sapped. Technological innovation and the engineering mind-set somehow went hand in hand with increasing mediocrity and the loss of (the longing for) practical wisdom, which expressed itself in poorer qualities of thought, feeling, and action. Tocqueville argued:

If the brilliant talkers and writers of that time [eighteenth century] were to return to life, I do not believe that gas, or steam, or chloroform, or the electric telegraph, would so much astonish them as the dullness of modern society, and the mediocrity of modern books (cited in Ossewaarde 2004: 157).

According to Tocqueville, industrial technologies require guidance through the statesman's virtue of prudence, if democratic culture was to affect the common people. Though Tocqueville accepted the destruction of the aristocratic world he admired for its grandeur, he believed that only statecraft and citizenship could ensure (political) freedom, humaneness, and humanization of the people. Tocqueville emphasized that democratic culture - which he saw as the promise of modernity and the only way not to end up as slaves - was not served by mechanical science but by classical and humanist 
philosophy and ancient scepticism. It was not engineering but the continuation of the ancient paideia that would make democracy work and would make statesman and citizens wise and strong enough to resist the administrative despotism that he saw as the probable outcome of mechanization.

After Comte and Tocqueville, the first 'crisis of modernity' discourse came to include new variants of technological optimism and pessimism. Like Comte, Karl Marx embraced socialism, but more than Comte, he identified capital as the force that threw modernity in crisis as it reduced workers to the status of things (Holloway 2012). The crises of 1848 and 1857-1958 were, for Marx, immanent to the class antagonism that was generated by exploitation in the factories. Since humanity and sociality, for Marx, were defined by labour - that is, by human creativity - he did not believe such dehumanization of workers could be a structural condition. Instead, he believed that the newly developed industrial working class, once mobilized, could gain mastery over technology. Only then would industrial technology become a worker's tool for the making of a more humane society for workers. Like Comte, and in contrast with Tocqueville, Marx had faith in the liberating potential of industrial technology that served the human creativity of those who owned it. German scholars like Georg Simmel, the Weber brothers, and Carl Schmitt profoundly disagreed with the technological optimists. Unlike Tocqueville's technological pessimism, theirs was not defined by ancient scepticism but by a 'romantic uneasiness' (cf. Mitcham 1994: 298). Like Tocqueville, they rejected mechanization and socialism as forces that would destroy European culture and give birth to 'the perfect herd animal, a veritable dwarf,' as Alfred Weber (1947: 112) put it. Scholars like the Weber brothers emphasized that European culture was defined by the Kulturmensch - by creative geniuses like Goethe and Beethoven. The destruction of the higher cultural ideals of Bildung through industrial development, in their view, had paved the way for World War I: mechanized warfare had come to crush humanity (Turner 2011).

\section{The Second 'Crisis of Modernity' Discourse}

After World War I, industrial capitalist society was marked by new turmoil, brutalization, hyper-inflation in 1922-3, the Wall Street Crash (1929), vulnerability to total economic collapse in Germany in 1929, the Great Depression of the 1930s, and the rise of totalitarianism - the breeding ground for new catastrophes and for the second 'crisis of modernity' discourse (Roseman 2011; Harrington and Roberts 2012). More than the first discourse, this second discourse resolved around financial crises and the Keynesian welfare state as the way out of such crises (Dahrendorf 2008: 52; Petersen and Petersen 2013; Berend 2013: 4). The redistributive welfare state was organized for the regulation of industrial capitalism. It spent large sums of taxpayers' money on social programs and large-scale technological initiatives - and, accordingly, fostered further mechanization - to foster full employment and generate social justice. The second 'crisis of modernity' discourse was defined by the clash between (Keynesian) liberal and radical scholars. The liberals were technological optimists that, even though they may not have shared Comte's socialism, continued the Comtean project. From the liberal point of view, the welfare state was the more attractive, civil alternative to the totalitarian statehood of Nazi Germany and the Soviet Union (Carney 1994: 477). The radicals 
were technological pessimists that formulated Tocquevillian and Weberian critiques of the welfare state apparatus and its large-scale technological initiatives. The second 'crisis of modernity' revealed conflicting priorities: technological and economic progress and humanitarian reform within the framework of industrial capitalism in the case of the liberals and paideia-based democratic culture and Bildung outside the established framework in the case of the radicals. The radicals sought to spread the European culture of the political and cultural elites among the common people. The key scholarly arguments of the second 'crisis of modernity' discourse are the following.

The distinguishing mark of the liberal scholars of the second discourse is that they legitimized the administrative apparatus of the Keynesian welfare state. They discussed the birth of the Keynesian welfare state as part of the history of the 'rights revolution' and of upward social mobility, facilitated by industrial technology (Haiven and Khasnabish 2014: 163). For liberals, industrial technological development, facilitated by the Keynesian welfare state, shaped the space of upward social mobility for workers on their way to becoming middle class. A liberal scholar like Richard Titmuss (1958: 36) noted that the welfare state was 'the Middle Class State,' whose aim was to transform the working classes into middle classes, through social engineering and the enforcement of 'humanistic ethics and the social rights of citizenship' (Titmuss 1964: 34). Likewise, a liberal like Thomas Humphrey Marshall (1950) defined the Keynesian welfare state as the guardian of social citizenship rights. Such rights were a new set of legal entitlements to welfare - claims that could only be developed in a highly mechanized society of large-scale health care, education, and social security systems. Liberal scholars tended to think of social policies, designed to materialize social citizenship rights, as 'social technologies.' They identified them as coded programs aimed at the control or transformation of administered capitalism, through social engineering (cf. Mitcham 1994: 149).

For liberal scholars, the threat to modernity came from the totalitarian (communist) world. Totalitarianism, they argued, was to be defeated by enforcing middle class worldviews and by developing industrial technologies that would be superior to the ones developed in the communist world. For radical scholars, on the other hand, the main threat to democratic culture and Bildung came from the Keynesian welfare state - an administrative apparatus that worked to mechanize the world. Pitirim Sorokin critically remarked that the liberal conviction that the welfare state represented the only good alternative to that other evil option reflected ideological bias, self-applause, and intellectual mediocrity. Sorokin (1941) argued that liberalism was itself a symptom of the 'crisis of modernity.' In line with the technological pessimists of the first 'crisis of modernity' discourse, Sorokin argued that liberalism signalled a paralysis of the creative powers of the mind and the collapse of the higher (or academic) aspirations of democracy, humanization, and Bildung. For Sorokin, indeed, the barbarism of the twentieth century did not manifest itself only in genocides, concentration camps, and totalitarian states. Also in the liberal welfare state, the common people were trapped in the Comtean tangible arrangement of things that Lewis Mumford (1971:29) at the time called 'megatechnic institutions and structures.'

All radical scholars discussed the paralysis of the creative powers of the mind and the regress of academic culture, for which they blamed liberal hegemony. Mills (1959: 175) questioned whether we must not face 'the possibility that the human mind as a social fact might be deteriorating in quality and cultural level, and yet not many would 
notice it because of the overwhelming accumulation of technological gadgets.' Since the common people look up to its political elites, Mills (1956: 354) mercilessly condemned 'the mindlessness and mediocrity of men of affairs,' who did not even pursue the paideia ideal of statesmanship. These 'new men of power,' Mills argued, were no longer educated by philosophy and were no longer committed to popularizing the higher (academic) culture of the mind. Instead, they allowed themselves to be informed by the mass media and entertainment industries. 'George Washington in 1783 relaxed with Voltaire's 'letters' and Locke's 'On Human Understanding'; Eisenhower read cowboy tales and detective stories,' Mills (1956: 350) critically remarked. Another technological pessimist, Arnold Gehlen, emphasized that with the mechanization of the world, the romanticist and culturally elitist Bildungsideal would inevitably vanish from the imagination. Being administered, people would lose their creativity and imagination and take 'ready-made beliefs and opinions from the state, press, media' (Gehlen 1980: 56-57). In a similar vein, Mumford (1971: 415; 435) spoke of 'the technodrama' and 'the technocratic prison,' which, in his view, had become a reality of a mechanized world in which industrial technology dominated people. Such radical scholars - technological pessimists - contested the further mechanization of the world that is shaped by the welfare state apparatus, using both Tocquevillian and Weberian arguments, in defence of the paideia or Bildung.

In the second 'crisis of modernity' discourse, the critical theorists of the Frankfurter Schule articulated critiques of liberalism that were somewhat different from those voiced by the radicals. The critical theorists shared the radical anti-capitalism of Marx, while they embraced the culturally elitist Bildungsideal of the German romanticists. They were mostly technological pessimists. Max Horkheimer and Theodor Adorno observed that new technologies like radio and film had facilitated the spreading of popular myths, dream worlds, mentalities, standardized tastes, and preferences; in other words, industrial technology was used to create mass deception (Feenberg 1991, 2002, 2008). Auschwitz and Hollywood were two sides of the same coin for Horkheimer and Adorno (Geuss 2005: 56). Other Frankfurt scholars, such as Herbert Marcuse (1968), did agree with the core diagnosis of the dialectic of enlightenment. Marcuse noted the negation of creativity and imagination in engineered mass deception, hence his 'onedimensional man' (Marcuse 1968: 53). But Marcuse refused to give up his Marxian faith in the liberating potential of technology, beyond mechanistic schemata (Feenberg 1991: 75; Garlick 2013). For Marcuse, the challenge was to realize the Bildungsideal and if this cultural ideal was realized, then culturally educated people would be able to make good use of technology in the service of humanization. Then technology would not be a form of control but a tool that would enhance cultural flourishing. In other words, Marcuse was uneasy with industrial technology and the mechanization of the world, but unlike Horkheimer and Adorno, he believed in a possible reconciliation between Bildung and technological advancement.

\section{The Third 'Crisis of Modernity' Discourse}

By the 1970s, a heavily indebted welfare state appeared unable to keep inflation under control. The Keynesian welfare state could not be sustained in the new world of financial capitalism. Profits from manufacturing, facilitated by industrial technologies, 
had dropped significantly; the power and credibility of labour unions had declined; and the share of wages in GDP had fallen. The producers of real wealth (industry, agriculture, and so on) had been superseded by powerful financial operators. Finance, financial technology, speculation, insurance, real estate, branding, consultancy, and ICT and data business were the new engines of wealth creation (Jessop 2010; Christophers 2012; Markantonatou 2013; Walby 2013; Berend 2013: 2; Haiven 2014b; Perrotini 2015; Bertolotti and Magnani 2015). The major profits were now reaped from loanable capital (banking sector, financial markets) and the circulation of capital. The so-called revolution in finance (Robinson 2012) meant that technological development found its most profitable outlet in speculation, that is, in derivatives, swaps, future markets, hedge funds, investment funds, mortgage-backed securities, collateralized debt obligations, Ponzi schemes, pyramiding of assets, etc. (Haiven 2014a; Gkanoutas-Leventis and Nesvetailova 2015). The third 'crisis of modernity' discourse resolves around such financialization of the world. While in the second 'crisis of modernity' discourse, scholars identified the Keynesian welfare state as the engine of mechanization, in the third discourse, mechanization is discussed in terms of 'financialization' and the rise of new, derivative-based, financial technologies.

The distinguishing feature of the third discourse is that scholars from both the liberal and the radical sides contest financialization. While liberal scholars had legitimized the welfare state as the engine of mechanization, they reject the financialization of the world as a post-Keynesian or neoliberal arrangement of things that fails to deliver full employment, social citizenship, and social justice. With the development of the postKeynesian welfare state, established to overcome the financial crises of the 1970s through the revolution in finance, government and citizens have become dependent on hedge funds, pension funds, insurance funds, real estate funds, and speculators (Palomera 2014; Haiven 2014a). Strange (1986: 4) observes that the (real) economy had become dependent on an unstable international financial system, to such an extent that it has become the 'rootstock, from whose disorders stem the various problems which afflict the international political economy, just as blight, disease, or mildew attack the different branches of a plant.' Ironically enough, liberal governments themselves had ignited the revolution in finance when they started to deregulate financial markets. Strange (1986: 52) notes that

Cloaked (as policy often is) in the fine-sounding rhetoric of liberal ideology, it was actually driven in the latter case by the very strong material interests of some of the biggest and most successful American corporations and their banks, supported by their lobbyists in Washington and promulgated by influential writers, journals and newspapers.

Strange points out that governments or regulators have systematically been lagging behind in the revolution in finance. 'Financial technology,' Strange (1986: 27) notes, 'invents totally new credit instruments or forms of financial transaction that the regulatory authorities never even dreamed of.'

Liberal scholars point at the impact of the new (derivative-based) financial technologies on the emancipation of finance from governmental control. Cooper (2010: 178) explains that 'derivatives challenge the idea that the circulation of money must be 
anchored in some fundamental, underlying value' and that such derivatives do no longer find 'any nominal foundation in the nation-state' (Cooper 2010: 179). Derivatives are tools that allow corporations to hedge against the occurrence of unpredictable, adverse events, with prices assigned to future happenings. While derivatives were previously used to speculate on real commodities, Cooper explains, with the revolution in finance, they are applied to non-storable 'products' like weather derivatives. Nigel Dodd (2011) points out that some of the riskiest financial instruments, such as collateralized debt obligations (CDOs), have been designed to avoid risk in speculation activities. Dodd explains that such financial technologies financialize money: money is treated as an instrument of speculation, without welfare states having control over such financial innovations. Dodd (2011: 190) emphasizes that this new type of mechanization reflects 'a pathological stage of capitalism, characterized by volatility and excess, seemingly driven by a financial distension that overwhelms the real economy and threatens the integrity of money as a secure store of value.'

Radical scholars re-articulate the Tocquevillian and Weberian arguments. They explain that financialization signifies a further mechanization of the world in which democracy and Bildung are dominated by finance. Winner (1980: 126) witnesses 'an ongoing social process in which scientific knowledge, technological invention, and corporate profit reinforce each other in deeply entrenched patterns that bear the unmistakable stamp of political and economic power.' Since small businesses, farmers, and artisans - actors of the real economy - cannot hedge themselves against the financial uncertainty and risks inherent in the post-Keynesian financial system, Winner points out, they are crowded out by big financial corporations. The post-Keynesian reforms of the 1970s were legitimized through technological optimism surrounding the prospects of the new derivative-based technologies, rather than through democratic debate or legislation. As Winner (1980: 135) explains, 'in our times people are often willing to make drastic changes in the way they live to accord with technological innovation at the same time they would resist similar kinds of changes justified on political grounds.' Hence, Winner's radical critique of financialization was as follows: finance-driven mechanization and the enforcement of derivative-based financial technologies have come to shape a new power complex that abandons the higher commitments of democracy and Bildung. Radical scholars, accordingly, refer to a 'crisis of democracy' or 'post-democracy' that is produced by financialization (Guéhenno 1993; Bethke Elshtain 1995; Lasch 1995; Sklair 1997; Crouch 2004; Winner 2004; Lazzarato 2009; Sim 2010; Swyngedouw 2011; Habermas 2011; Blühdorn 2013; Wright 2013; Walby 2013: 503; Schenner 2016). Among other things, radical scholars witness this crisis of democracy in the impoverishment of everyday language and the loss of imagination of political alternatives. That is, the language of finance has become hegemonic; the corresponding mechanical ways of thinking, theorizing, and judging are enacted through a growing dependence of major sociotechnical systems on financialization (cf. Haiven 2014a; Chiapello 2015).

As mentioned before, radical scholars identify the 'crisis of modernity' as a crisis of the mind - the lowering of civic and intellectual standards that they believe comes with the mechanization of the world. In the second discourse, scholars like Mills observed the non-academic shallowness of the 'new men in power,' which for Mills applied to the liberal politicians of the 1940s and 1950s who arranged the administrative apparatus of the Keynesian welfare state. In the third discourse, liberal scholars apply this radical 
argument to the men in power within the post-Keynesian arrangements of things. While Mills (1956: 360-361) had identified Eisenhower as a 'second rate mind' who preferred the deceptive entertainment industries to philosophy, learning, and the quest for wisdom, the liberal scholar Michel Crozier manifests nostalgia to the liberal politicians of the 1940s and 1950s. Crozier criticizes the new men in power of the 1970s as Crozier (1984: 134) explains the 'contrast between a John Paul II or a de Gaulle and recent American presidents, Johnson, Nixon, or Carter-who look hopelessly immature by comparison.' And while the radical scholars of the second discourse identified the crisis of the mind with the rise of liberalism and the construction of the Keynesian welfare state, Crozier identifies the crisis of the mind with the crisis of the Keynesian welfare state. The crisis of the Keynesian welfare state, Crozier (1984: 147) insists, 'is not its relative impotence in maintaining its liberal creed in a shrinking world, it is its strange intellectual demise, its lack of enthusiasm for the intellectual pioneering of the future.'

Not only liberal and radical scholars but also critical theorists have responded to the financialization of the world. Today's critical theorists appear to have distanced themselves from the negative dialectics and melancholy that characterized the work of Horkheimer and Adorno. They, instead, look to new technologies for their liberating potentials and possible new reconciliations between technology and democracy. Yet they emphasize that new technologies are destined to facilitate oppression when technological development is governed through dependence on financialization. For Andrew Feenberg (1991: 3), the financialization of the world refers to enactment of 'anti-democratic values that govern technological development.' As a critical theorist, Feenberg emphasizes that technologies are not neutral or unbiased technical codes but carry within them an ideological code that is dependent on established (yet dynamic and contested) capitalist power relationships. In contrast to Horkheimer, Adorno, and Marcuse and like Marx, Feenberg (2008) does not believe that, in the current context of financialization, intellectual and aesthetic genius, cultural elitism, or Bildung can trigger transformations and cultural revitalization. In a more Marxian way, Feenberg argues that transformations develop from unsustainable contradictions within the economic sphere. He explains that the conflicts, crises, and problems caused by the financialized technological environment give rise to new technological controversies, lawsuits, moral dilemmas, and contestations. Such ambiguities, Feenberg's argument goes, can open up new technological possibilities and alternative power structures (such as digital commons that are characterized by abundance of information). And these alternative structures may come to embody democratic values rather than financial interests.

\section{The Continuation of the Third 'Crisis of Modernity' Discourse}

Since the financial crises of the 1970s and the enactment of the post-Keynesian power structure, more than a hundred financial crises have emerged (Castree 2009; Berend 2013). The biggest of these is the global financial crisis. The crash of real estate markets, banking, and corporate failures, the slowdown in international trade, widespread capital flight, and a fiscal crisis of many states have revealed the failure of postKeynesian welfare state's regulation and governance of markets (Gkanoutas-Leventis 
and Nesvetailova 2015). While, previously, a crisis of such a scope typically triggered a new 'crisis of modernity' discourse, with the global financial crisis and its aftermath, this has not been the case. This is because scholars have discussed the global financial crisis and the rise of new financial technologies in terms of the insights delivered by the third discourse. The post-Keynesian complex is criticized for being devoid of democratic and cultural aspirations, and no post-neoliberal arrangement has come into place to overcome financial crises (Sim 2010; de Benoist 2011; Coyle 2011: 217; Tassone 2013: 91). In other words, the third 'crisis of modernity' discourse continues. The global financial crisis, however, was the biggest crisis since the Great Depression. This is the reason why scholars like Harrington and Roberts (2012: 4) argue that the Weimar experience can be seen as the model for the present condition of post-democracy:

The collapse of Western financial markets in 2008 and the ensuing recession has indeed been only another reminder of commonalities with the past as the myopia of governments addicted to neoliberal economic policies resembles ever more closely the perilous state of affairs of degraded social solidarity in Europe after 1918.

In other words, despite the fact that mechanization has become far more complex than a few decades ago, the causes of the different financial crises can be partly be traced back to the crisis of democracy and the decline of the elitist Bildungsideal. This means that the insights of the first 'crisis of modernity' discourse are not 'outdated' and can, instead, shed light on the present predicaments of the crisis-prone financialized world and the rise of the new algorithm-based financial technologies within the context of the neoliberal power structure.

Today, scholars widely observe that the post-Keynesian arrangement of things and its financialization of the world has lost its legitimacy (Jessop 2010: 43; Calhoun and Derluguian 2011: 8; Charnock et al. 2012; Robinson 2012; Thompson 2012; Rosenhek 2013; Wright 2013: 22). The loss of legitimacy is expressed in worldwide protests that are typically labelled as 'post-11 movements' (see Davis et al. 2016), like Occupy Wall Street, Blockupy Frankfurt, and the Indignados movement, as well as movements like Wikileaks and Anonymous (Swyngedouw 2011; Turner 2011; Kalb 2012; TaylorGooby 2013: 2). Scholars assess the meaning of such protests in different ways. Tocquevillian and Weberian scholars witness such protests with a certain scepticism, that is, they are conceived of as revolts of the furious crowds (Ossewaarde 2013). The possibility of shaping democratic culture and realizing Bildung, it is argued, depends on educated political, corporate, and cultural elites informed by philosophy, not on crowds. Marxian scholars, by contrast, identify the protests as a revolutionary movement of the working classes against financial capitalism and its rulers from Wall Street (Kalb 2012; Haiven and Khasnabish 2014: 35). Liberal scholars argue that the protests are a struggle for rights and against austerity measures. They identify such post-Keynesian measures as 'monetary bloodshed,' in the words of Bertolotti and Magnani (2015: 290). They emphasize that the dismantling of the liberal welfare state makes that particularly younger generations are saddled with the unresolved issues of excessive debt, diminished prospects, and downward social mobility (Castree 2009: 196; Robinson 2012). Radical scholars, by contrast, point at the ongoing decline of, and the need to rebuild, the radical mind-set of great transformers. As Haiven and Khasnabish (2014: 3-4) 
argue, 'without the radical imagination, we are left only with the residual dreams of the powerful, and for the vast majority they are not experienced as dreams but as nightmares of insecurity, precarity, violence, and hopelessness.' Such radical scholars are inclined to identify the protest movements as quests for a renaissance- a cultural renewal that cannot be hoped for within the tangible arrangements of a financialized world.

In the second discourse, liberal scholars had been technological optimists who legitimized the mechanization schemes of the Keynesian welfare state. Statesponsored technology secured new employment and would contribute to generating higher levels of social justice. In the third discourse, liberal scholars appear sceptical about new financial technologies, as these may not be helpful for fulfilling the Keynesian aspirations but, instead, tend to contribute to further financialization. Both liberal and radical scholars argue, in line with the currents of the second and third 'crisis of modernity' discourses, that the crisis of the mind is such that the creativity and imagination needed to negate and transcend the post-Keynesian power structure is lacking (Castree 2009; Chorev and Babb 2009: 477-8; Marquand 2011: 18; Holloway 2012: 517; Dinerstein 2012; Wright 2013; Haiven and Khasnabish 2014). Radical scholars in particular understand this crisis of the mind in the context of the global financial crisis as a deep cultural crisis, 'dark times' (Haiven and Khasnabish 2014: 1) where the slippery slope to the 'degeneration into a new 'Dark Ages',' characterized by radical mechanization and loss of commitment to paideia-based democracy and Bildung, is very much present (Robinson 2012: 170). Scholars observe that the response of the global financial crisis has been one in which the delegitimized (and oppressive) arrangement of things has been further enforced (Streeck 2011; Walby 2013: 493; Tassone 2013: 91). As Crouch (2011: viii) puts it, 'neoliberalism is emerging from the financial collapse more politically powerful than ever.' Similarly, Abolafia (2010: 98) notes that 'given the current state of campaign finance, it is the financial industry itself that will decide on the redesign of its regulatory system.'

Technological pessimists emphasize that given the current cultural crisis (without much prospect of a new humanist renaissance) and the established status quo, the use of financial technologies in the financialized world is potentially catastrophic. And such technological pessimists argue that the current cultural crisis, characterized by a deep anti-intellectualism, is brought about by a transformation of the mechanization process. With the rise of the new financial technologies, the practice of making and using machine codes is divorced from the rules of mechanical science. Louise Amoore (2011) and Mackenzie and Vurdubakis (2011) explain that in algorithmic trading, like high frequency trading (HFT), Newtonian thought processes are replaced by data integration, data mining, and data analytics - all designed to extract patterns of relations from gathered data. Such pattern recognition, Amoore (2011: 32) stresses sceptically, embodies 'an indifference to conventional Galilean scientific notions of evidence and accuracy'. Strategic priority of the current algorithmic technologies used to more and more financialize the world is speed, not knowledge or philosophy, let alone democratic culture or Bildung (Arnoldi 2016). Moreover, Mackenzie and Vurdubakis (2011), Amoore (2011), and Marc Lenglet (2011) stress, in a technological pessimist fashion, that algorithmic codes are by definition ambiguous. Lenglet (2011: 48) argues that 'algorithms embody a controversial (thereby political) space' occupied by a power constellation of market regulators, market supervisors, traders, brokers, programmers, 
hardware designers, risk managers, marketers, salespersons, etc. whose prejudices, dogmas, bias, clichés, and dispositions are concealed in what Amoore (2011: 38) calls 'the glossy technoscientific gleam of the risk-solution'. In other words, the financialization that is further promoted by new algorithmic technologies is presented as unambiguous engineering but is in fact a political act that is performed within the boundaries of the post-Keynesian constellation. Hence, it is possible to speak of the neoliberal politics of the algorithmic technologies.

Yet the third 'crisis of modernity' discourse not only includes technological pessimists. Liberal scholars in particular are technological optimists and tend to argue that the algorithmic financial technologies may provide the tools for negating the postKeynesian power complex. Liberal scholars like MacKenzie (2015) and Bjerg (2016) argue that although it may be true that, given the crisis of the mind, no new alternative world can be imagined beyond the financialized world, new financial technologiesincluding cryptocurrencies, blockchain technology and high frequency trading-have emerged from the global financial crisis that may well disrupt the post-Keynesian order. Algorithmic financial technologies, the argument goes, radicalize the mechanization of the financial world from below, often via start-up companies (Mackenzie and Vurdubakis 2011; Arnoldi 2016). The hundreds of cryptocurrencies that exist today make it possible to bypass the established power complex: these are types of money that are produced and validated in global networks without banks or government (MacKenzie 2015; Bjerg 2016). Similarly, local exchange trading systems-democratically organized community enterprises that record transactions by using locally created currencies - negate the administrative apparatus of banks and governments and reconcile local democracy and (local) finance (Fraňková et al. 2014). Blockchain technology, originally developed to register bitcoin transactions, technological optimists believe, is another technology that is a potentially disruptive force from below. Blockchain is an electronic ledger that uses software algorithms to record transactions with machinebased reliability and anonymity and believed to be immune to financial crime or political control (Bjerg 2016). In sum, technological optimists welcome the rise of the algorithmic technologies for two reasons: first, because such technologies make it possible to disrupt the post-Keynesian order and, second, because computer algorithms are more reliable than governments and banks (MacKenzie 2015).

Other scholars, in line with the critical theoretic works of Feenberg, see in the global financial crisis new hope for what Sclove (1995: 97) calls 'technological democratization' from below, through grassroots involvement in governing technological development beyond mechanization or financialization. They seek to renew democratic commitments, in the context of the global financial crisis and the worldwide protests it has ignited. Tom Malleson (2014), for instance, notes that the Occupy movement has brought the possibility of an 'economic democracy' into view, with its plea for postcapitalist practices like worker cooperatives, public banks, and participatory investments-bottom up initiatives that seek to bring crucial decision-making from the boardroom to the democratic arena. In other words, Malleson emphasizes that political behaviour is a core feature of shaping technology. Similarly, Dotson (2012: 329) bemoans the 'mix of triumphant technological determinism and individualistic libertarianism' that, in his view, characterized the current dependence on financialization. He believes that the responsibility for sorting out desirable technologies from undesirable ones may no longer be left to innovators, governments, businesses, and markets 
(Dotson 2015). Carlo Vercellone (2015) believes that new technologies could make it possible to re-establish Keynesian mechanisms that subject monetary policy to a power complex that is expressive of a democratic community-for instance, through a communalization of the banking system, facilitated by new financial technologies that require no banks and no governments. The imagined alternatives, it is argued, will make it more difficult for the neoliberal status quo to pretend that algorithmic mechanization is a blind, a political, and a cultural process. In sum, such scholars are technological optimists in the sense that they emphasize that the new financial technologies may be employed to negate financialization and pave the way for political and cultural renewal.

\section{Concluding Remarks}

In this article, three 'crisis of modernity' discourses, which developed in response to the political and financial crises of the last two centuries, have been discussed. In the context of these three discourses, scholars have generated competing arguments of technology and modernity, and they have theorized the technological change process and its impacts on democracy and high (intellectual or academic and aesthetic) culture. The first discourse emerged in the context of Industrial Revolution and the aftermath of the French Revolution - it arose in the post-aristocratic society that was in the making. The discourse of this period is crucial for later centuries, till now, because the conflicting foundations of theorizing modernity were then laid. The Comtean legacy is very much ingrained in contemporary modern consciousness and the making of a financialized and algorithmic world defined by ongoing mechanization. But the Tocquevillian and Weberian legacies, characterized by a profound technological pessimism and distaste for mechanization, have not gone lost. The second 'crisis of modernity' discourse developed in the context of the Great Depression of the 1920s1930 s and the making of the Keynesian welfare state that was deeply interwoven with technical systems - designed to overcome financial crises - of various kinds. Liberal scholars like Keynes, Titmuss, and Marshall identified technological development as a way of creating new employment, for instance, via infrastructural projects, in an organized world of regulated capitalism. Radical scholars, by contrast, criticized the Keynesian arrangement of things as an administrative apparatus complex established to mechanize the world - and thereby make worlds administrable at the expense of creative powers of the mind. Scholars like Gehlen, Mumford, and Mills all noted that, as ruling political and corporate elites betrayed their democratic and cultural ideals, people had been mechanized into machine-like, programmable beings (Mills emphasized that technologies increasingly script social behaviour of what he called 'cheerful robots'). In this second discourse, Horkheimer and Adorno argued that the scholarly challenge was to demythologize the liberal world of industrial capitalism and its deceptive, mechanizing and standardizing culture industries that were governed by the vested interests of ruling powers at the expense of the mind.

The third 'crisis of modernity' discourse developed in response to the financial crisis of the 1970s. The Keynesian constellation had given way to the post-Keynesian welfare state. In this third discourse, liberal and radical scholars alike point at cultural regress, de-democratization, and the spreading of political and cultural nihilism under the rule 
of finance. Industrial mechanization now comes to assume the form of (post-industrial) financialization. In this third discourse, it is typically stressed, in a highly critical way, that new technologies, particularly, new derivative-based financial technologies, are mainly produced within a neoliberal order which distributes such technologies to push for further financialization. Contemporary thinkers have noted the loss of legitimacy of the post-Keynesian constellation, which has failed to prevent and solve the many financial crises of the financialized world (Castree 2009). The lack of creativity to imagine and create alternative, legitimate, and democratic arrangements of things has also been noted (Haiven 2014b). The anti-intellectualism that determines the direction of financialization is mainly reinforced by further mechanization that is governed by the financial interests of the ruling political and corporate elites of the financialized world. The rise of the algorithmic technologies must be understood in the context of this reinforcement. These are technologies that bracket out the politically constructed nature of markets within the post-Keynesian arrangement of things (Dotson 2012: 330). In other words, inasmuch as the technological projects of the welfare state had depended on a Keynesian power complex, the rise of the new financial technologies is less dependent on their algorithmic nature than upon a post-Keynesian constellation (cf. Dawson and Buchanan 2005).

Several continuities in 'crisis of modernity' discourses since the 1830 s can be identified in current discussions of financial crises and the role of financial technologies therein. Contemporary 'crisis of modernity' discourses, developed in the context of the global financial crisis, however, have brought to light a new worrisome phenomenon, namely, the absence of an intellectual alternative to financialization. 'Crisis,' Antonio Gramsci (1971: 276) aptly explains, 'consists precisely in the fact that the old is dying and the new cannot be born; in this interregnum a great variety of morbid symptoms appear.' According to Gramsci, crisis spells the doom of a particular period, but it is temporary, an intermediate state towards something new. In 'crisis of modernity' discourses, crises are therefore discussed as the potential harbingers of new epochs, typically including Tocquevillian and Weberian visions that point beyond mechanization trajectories. Yet, in the third discourse, particularly in the context of the global financial crisis, scholars have a tendency to identify the 'morbid symptoms' as structural conditions of 'post-democracy,' marked by neoliberal domination. This means that the 'morbid symptoms' that were meant to belong to an interregnum are institutionalized within the post-Keynesian order. It is within this pathological condition that the new algorithmic technologies have emerged. Technological pessimists stress that such new financial technologies are not informed by democratic commitments and the Bildungsideal. Technological optimists argue that algorithmic technologies may disrupt the post-Keynesian order and shape something new from below - a new world shaped from outside the academy.

The big question is whether enough intellectual and moral powers can be rallied to resist further mechanization/financialization, given an established arrangement of things in which powers do not even seek legitimacy to rule (Crouch 2004; Della Porta 2013: 1). The governmental response to the global financial crisis has not been one in which the post-Keynesian order has been negated; quite the contrary, as Abolafia (2010) and Crouch (2011) explain, it has been reinforced. Making democracy work or realizing the Bildungsideal in the contemporary, technological environment of financial capitalism inevitably implies a de-financialization of the world. Scholars like Tocqueville and Weber and the radicals of the second discourse teach that the 
possibility of de-financialization depends less on algorithmic technologies (which continue or radicalize the mechanization process) than on a reconfiguration of postindustrial (financial and technological) powers on a global scale. This reconfiguration de facto means the negation and transcendence of the dependence on financialization. It means cultural renewal - a renaissance, to break out of the crisis of the mind (Walby 2013). But such radical reforms, which demand a high dose of political courage and cultural commitment, will not take place in the near future, unless hopeful scholars like Marcuse, Feenberg, Malleson, and Dotson are right in their argument that the cultural crisis of the mind is not so extreme yet and that, accordingly, technology, in the right hands, may well become the tools for negating mechanization and for stimulating humanization and liberation from illegitimate power relationships.

Open Access This article is distributed under the terms of the Creative Commons Attribution 4.0 International License (http://creativecommons.org/licenses/by/4.0/), which permits unrestricted use, distribution, and reproduction in any medium, provided you give appropriate credit to the original author(s) and the source, provide a link to the Creative Commons license, and indicate if changes were made.

\section{References}

Abolafia, M. Y. (2010). Can speculative bubbles be managed? An institutional approach. Strategic Organization, 8(1), 93-100.

Amoore, L. (2011). Data derivatives: on the emergence of a security risk calculus for our times. Theory, Culture \& Society, 28(6), $24-43$.

Arnoldi, J. (2016). Computer algorithms, market manipulation and the institutionalization of high frequency trading. Theory, Culture \& Society, 33(1), 29-52.

de Benoist, A. (2011). The current crisis of democracy. Telos, 156, 7-23.

Berend, I. T. (2013). Europe in crisis: bolt from the blue. London: Routledge.

Bertolotti, T., \& Magnani, L. (2015). Contemporary finance as a critical cognitive niche: An epistemological outlook on the uncertain effects of contrasting uncertainty. Mind and Society, 14, 273-293.

Bjerg, O. (2016). How is Bitcoin money? Theory, Culture \& Society, 33(1), 53-72.

Blühdorn, I. (2013). The governance of unsustainability: ecology and democracy after the post-democratic turn. Environmental Politics, 22(1), 16-36.

Calhoun, C., \& Derluguian, G. (2011). The deepening crisis: governance challenges after neoliberalism. London: New York University Press.

Carney, L. (1994). Sociology in the throes of fascism: Parsonian meliorism and myths of triumphalism. International Journal of Politics, Culture and Society, 7(3), 469-483.

Castree, N. (2009). Crisis, continuity and change: neoliberalism, the left and the future of capitalism. Antipode, 41(s1), 185-213.

Charnock, G., T. Purcell and R. Ribera-Fumaz (2012). ¡Indígnate!: the 2011 popular protests and the limits to democracy in Spain. Capital \& Class, 36(1), 3-12

Chiapello, E. (2015). Financialisation of valuation. Human Studies, 38, 13-35.

Chorev, N., \& Babb, S. (2009). The crisis of neoliberalism and the future of international institutions: a comparison of the IMF and the WTO. Theory and Society, 38(5), 459-484.

Christophers, B. (2012). Anaemic geographies of financialisation. New Political Economy, 17(3), $271-291$.

Comte, A. (2000). The positive philosophy of Auguste Comte (Vol. 1). London: Batoche Books Kitchener.

Comte, A. (1974). The crisis of industrial civilization: the early essays of Auguste Comte. London Heinemann.

Cooper, M. (2010). Turbulent worlds: financial markets and environmental crisis. Theory, Culture \& Society, 27(2-3), 167-190.

Coyle, D. (2011). The economics of enough: how to run the economy as if the future matters. Princeton and Oxford: Princeton University Press.

Crouch, C. (2004). Post-democracy. Cambridge: Polity Press.

Crouch, C. (2011). The strange non-death of neoliberalism. Cambridge: Polity Press.

Crozier, M. (1984). The trouble with America. London: University of California Press. 
Dahrendorf, R. (2008). The modern social conflict: the politics of liberty, completely revised (second ed.). London: Transaction Publishers.

Davis, T., Ryan, H. E., \& Peña, A. M. (2016). Protest, social movements and global democracy since 2011: new perspectives. Research in Social Movements, Conflicts and Change, 39, 1-29.

Dawson, P., \& Buchanan, D. (2005). The way it really happened: competing narratives in the political process of technological change. Human Relations, 58(7), 845-865.

Della Porta, D. (2013). Can democracy be saved? Participation, deliberation and social movements. Cambridge: Polity Press.

Dinerstein, A. C. (2012). Interstitial revolution: on the explosive fusion of negativity and hope. Capital \& Class, 36(3), 521-540.

Dodd, N. (2011). 'Strange money': risk, finance and socialized debt. British Journal of Sociology, 61(1), $175-194$.

Dotson, T. (2012). Technology, choice and the good life: questioning technological liberalism. Technology in Society, 34, 326-336.

Dotson, T. (2015). Technological determinism and permissionless innovation as technocratic governing mentalities: psychocultural barriers to the democratization of technology. Engaging Science, Technology, and Society, 1, 98-120.

Elshtain, J. B. (1995). Democracy on trial. New York: Basic Books.

Feenberg, A. (1991). Critical theory of technology. Oxford: Oxford University Press.

Feenberg, A. (2002). Transforming technology: a critical theory revisited. Oxford: Oxford University Press.

Feenberg, A. (2008). From critical theory of technology to the rational critique of rationality. Social Epistemology, 22(1), 5-28.

Fraňková, E., Fousek, J., Kala, L., \& Labohý, J. (2014). Transaction network analysis for studying Local Exchange Trading Systems (LETS): research potentials and limitations. Ecological Economics, 107, 266-275.

Garlick, S. (2013). Complexity, masculinity, and critical theory: revisiting Marcuse on technology, Eros, and nature. Critical Sociology, 39(2), 223-238.

Gehlen, A. (1980). Man in the age of technology. New York: Columbia University Press.

Geuss, R. (2005). Outside ethics. Princeton: Princeton University Press.

Gkanoutas-Leventis, A., \& Nesvetailova, A. (2015). Financialisation, oil and the Great Recession. Energy Policy, 86, 891-902.

Gramsci, A. (1971). Selections from the prison notebooks. New York: International Publishers.

Guéhenno, J.-M. (1993). La fin de la démocratie. Paris: Flammarion.

Habermas, J. (2011). Europe's post-democratic era. The Guardian, 10 November 2011.

Haiven, M. (2014a). Cultures of financialization: fictitious capital in popular culture and everyday life. Basingstoke: Palgrave Macmillan.

Haiven, M. (2014b). The creative and the derivative: Historicizing creativity under post Bretton Woods financialization. Radical History Review, 118, 113-138.

Haiven, M., \& Khasnabish, A. (2014). The radical imagination: social movement research in the age of austerity. London: Zed Books.

Harrington, A., \& Roberts, D. (2012). Introduction: Weimar social theory: the 'crisis of classical modernity' revisited. Thesis Eleven, 111(1), 3-8.

Holloway, J. (2012). Crisis and critique. Capital \& Class, 36(3), 515-519.

Jessop, B. (2010). The "return" of the national state in the current crisis of the world market. Capital \& Class, 34(1), 38-43.

Kalb, D. (2012). Thinking about neoliberalism as if the crisis was actually happening. Social Anthropology, 20(3), 318-330.

Lasch, C. (1995). The revolt of the elites and the betrayal of democracy. New York: W.W. Norton.

Lazzarato, M. (2009). Neoliberalism in action: inequality, insecurity and the reconstitution of the social. Theory, Culture \& Society, 26(6), 109-133.

Lenglet, M. (2011). Conflicting codes and codings: how algorithmic trading is reshaping financial regulation. Theory, Culture \& Society, 28(6), 44-66.

MacKenzie, D. (2015). Mechanizing the Merc: the Chicago Mercantile Exchange and the rise of high frequency trading. Technology and Culture, 56(3), 646-675.

Mackenzie, A., \& Vurdubakis, T. (2011). Codes and codings in crisis: signification, performativity and excess. Theory, Culture \& Society, 28(6), 3-23.

Malleson, T. (2014). Economic democracy in the 21st century. Open Democracy, 15 August 2014.

Marcuse, H. (1968). One dimensional man. London: Sphere Books.

Markantonatou, M. (2013). Neoliberal state regulation and the bailout of global capitalism in the recent economic crisis. Critical Sociology, 39(1), 145-153.

Marquand, D. (2011). The end of the West: the once and future Europe. Oxford: Princeton University Press. 
Marshall, T. H. (1950). Social class and citizenship. Oxford: Oxford University Press.

Mills, C. W. (1956). The power elite. Oxford: Oxford University Press.

Mills, C. W. (1959). The sociological imagination. Oxford: Oxford University Press.

Mitcham, C. (1994). Thinking through technology: The path between engineering and philosophy. London: University of Chicago Press.

Mumford, L. (1971). The myth of the machine: the pentagon of power. London: Secker and Warburg.

Ossewaarde, M. R. R. (2004). Tocqueville's moral and political thought: new liberalism. London: Routledge.

Ossewaarde, M. (2013). The crowd in the Occupy movement. Distinktion: Scandinavian Journal of Social Theory, 14(2), 134-150.

Palomera, J. (2014). Reciprocity, commodification, and poverty in the era of financialization. Current Anthropology, 55(9), 105-115.

Perrotini, I. (2015). Profiting from financialization, secular stagnation and wage anchors: A commentary on Lapavitsas (2013). Dialectical Anthropology, 39, 329-336.

Petersen, K., \& Petersen, J. H. (2013). Confusion and divergence: origins and meanings of the term "welfare state" in Germany and Britain, 1840-1940. Journal of European Social Policy, 23(1), 37-51.

Robinson, W. I. (2012). 'The Great Recession' of 2008 and the continuing crisis: a global capitalism perspective. International Review of Modern Sociology, 38(2), 169-198.

Roseman, M. (2011). National socialism and the end of modernity. The American Historical Review, 116(3), 688-701.

Rosenhek, Z. (2013). Diagnosing and explaining the global financial crisis: central banks, epistemic authority, and sense making. International Journal of Politics, Culture and Society, 26, 255-272.

Schenner, J. K. (2016). Introduction: 'post-democracy': retrospect and prospect. The Political Quarterly, $87(1), 69-70$.

Sclove, R. E. (1995). Democracy and technology. London: The Guilford Press.

Sim, S. (2010). The end of modernity: what the financial and environmental crisis is really telling us. Edinburgh: Edinburgh University Press.

Sklair, L. (1997). Social movements for global capitalism: the transnational capitalist class in action. Review of International Political Economy, 4(3), 514-538.

Sorokin, P. A. (1941). The crisis of our age. Oxford: Oneworld.

Strange, S. (1986). Casino capitalism. Oxford: Basil Blackwell.

Streeck, W. (2011). The crisis of democratic capitalism. New Left Review, 71, 5-29.

Swyngedouw, E. (2011). Interrogating post-democratization: reclaiming egalitarian political spaces. Political Geography, 30(7), 370-380.

Tassone, G. (2013). Democracy at a standstill: the idea of democracy as a dialectic of theory and practice. Critique: Journal of Socialist Theory, 41(1), 77-92.

Taylor-Gooby, P. (2013). The double crisis of the welfare state and what we can do about it. Basingbroke: Palgrave Macmillan.

Thompson, H. (2012). The limits of blaming neo-liberalism: Fannie Mae and Freddie Mac, the American state and the financial crisis. New Political Economy, 17(4), 399-419.

Tiles, M., \& Oberdiek, H. (1995). Living in a technological culture: human tools and human values (pp. 1231). London: Routledge.

Titmuss, R. M. (1958). Essays on 'the welfare state'. London: George Allen \& Unwin.

Titmuss, R. (1964). The limits of the welfare state. New Left Review, 27, 28-37.

Turner, B. (2011). Max Weber and the spirit of resentment: the Nietzsche legacy. Journal of Classical Sociology, 11(1), 75-92.

Vercellone, C. (2015). From the crisis to the 'welfare of the common' as a new mode of production. Theory, Culture \& Society, 32(7-8), 85-99.

Walby, S. (2013). Finance versus democracy? Theorizing finance in society. Work, Employment and Society, 37(3), 489-507.

Weber, A. (1947). Farewell to European history or the conquest of nihilism. London: Kegan Paul.

Winner, L. (1980). Do artifacts have politics? Daedalus, 109(1), 121-136.

Winner, L. (2004). Trust and terror: the vulnerability of complex socio-technical systems. Science as Culture, 13(2), 155-172.

Wright, E. O. (2013). Transforming capitalism through real utopias. American Sociological Review, 78(1), 1-25. 